\title{
It is Perilous to be Old and Frail in the Land of More
}

\author{
Awad Magbri MD FACP, Suhail Aftab MD, Anita Moses, Karen Miller MSC RN \\ Surgery and Vascular Center at Regency LLC, Toledo, Oh.USA
}

\begin{abstract}
*Corresponding Author: Awad Magbri, MD FACP, Surgery and Vascular Center at Regency LLC, Toledo, Oh.USA, Email: elmagbri@ hotmail.com
\end{abstract}

Key words: Health care, insurance, decision-making, premiums, government regulations.

\section{EDITORIAL}

We all aware of the rising health care costs and the astronomical premiums that insurance companies charge the mistreated American citizens every day, even though, we may be partly to blame for most of the mischief behind the chaos. A few weeks ago, I was rounding on a 92-year old kindred spirit who was diagnosed with intractable heart failure. As he expressed his wishes for no interventions, no heroic measures, I subconsciously knew this might be his last visit ever to a hospital. "It was a meaningful life," he said smiling, "that's why I have lived so long."

Later that night, unfortunately, he had taken a turn for the worse. His heart failure exacerbation had left him gasping for air, challenging his ability to breathe. Given that he had several comorbid conditions with unsalvageable underlying heart failure, it was decided to proceed in accordance of his wishes to comfort care only. I forced myself to strongly resist the temptation of putting him on the ventilator, knowing that it wouldn't change his hospital course prediction. Our ability to predict what would happen next succumbed to the acknowledgement of uncertainty. Letting nature takes its course may be the best certitude of action.

However, his primary care physician (PCP), who had hardly seen him in the usual late-night rounds, had been briefed on the patient's state that night. To my astonishment, the PCP had decided to intubate and ventilate the poor man against his suppressed wishes-not only increasing the patient and his family's agony, but also ultimately adding to the financial burdens of health care costs.
Because of lack of diligent and honest conversation with the family, the decision of the PCP incurred 10 days on mechanical ventilation with $\$ 70 \mathrm{~K}$ to $\$ 100 \mathrm{~K}$ of extra-expenses to taxpayers' dollars. Ten grueling days on the artificial ventilator also came with multitudeof futile blood draws for fancy investigations and unavailing medications. Although the patient was no longer on my service, I eventually found out that the patient had been discharged from the hospital with home hospice care.

The United States is desolately unsuccessful in controlling medical care expenditure compared to other nations who spend less on medical care while attaining better satisfied outcome (1-3). If the private health insurers and Medicare imposed little effective control on the health care providers, as well as defensive medicine taken out of the equation then health care costs would not have been balloon-out of control (48).

Knowing the limitations of today's advanced medicine and how much we can offer to our patients is undeniably a virtue not everyone knows. Adopting policies to explicitly regulate beneficial medical services are steps needed to be taken (9-11). We as doctors undertake decisions every day on the premises of defensive medicine. But the question is, why do we inflict trauma, pain, and suffering on our patients who do not ask for it, only to satisfy our complicated high-achieving egos that we did "something" gratifying to our patients and their families? What happened to the dictum "First, do no harm"? The very same moral principles of medical mankind that brought us here (12). Why are we overestimating our capacity to heal? The fact is that progress have occurred in our health care over the last half-century, and therefore we 
must evolve and adapt those positive changes to benefit us all. It is our responsibility to go forth and educate our new generation of physicians on the harms they might inadvertently inflect by over treating the inevitable.

We, as health care providers, must know when to stop futile measures, and contest drastic measures because they are not good choice for our patients. The consequences of overtreatment may do more harm than good. The United States does have a comparatively high level of superfluous imaging units and patient surgeries than other industrialized nations $(13,14)$. Government regulations are known to be effective strategy to control health care spending and curtail useless measures (15-17).

Furthermore, the lack of effective counseling to our patients feeds into the health care costs related to repercussions from undisciplined lifestyle choices such as smoking, drinking, unhealthy eating habits, overuse of drugs (prescription and non-prescription) and the list goes on and on. In addition, the partially

\section{REFERENCES}

[1] Evans, RG. Devil take hindmost: private health insurance and rising costs of American exceptionalism. In Morone JA, Litman TJ, Robins LS, editors. Health politics and policy, 4th ed. Clifton Park (NY): Delmar Cengage Learning; 2008: 445-74

[2] Anderson GF, Frogner BK. Health spending in OECD countries: obtaining value per dollar. Health Aff (Millwood). 2008; 27(6): 1718-27

[3] Neumann PJ. Using cost-effectiveness analysis to improve medical care: opportunities and barriers. New York (NY): Oxford University Press; 2007: 57

[4] Anderson OW. Health services in a land of plenty. In environment and policy: The next fifty years, edited by Edward WR. Jr. Indiana University Press, Bloomington. 1968: 59-102. Google scholar.

[5] Fuchs VR. The growing demand for medical care. N Engl J Med. 1968; 279(4): 190-195. Google scholar Medline.

[6] Anderson GF, Reinhardt UE, Hussey PS, Petrosyan V. It's the prices, stupid: Why the United States is so different from other countries. Health Aff (Millwood). 2003; 22(3): 89-105

[7] Anderson GF, Hussey PS, Frogner BK, Waters HR. Health spending in the United States and the rest of industrialized world. Health Aff (Millwood) 2005; 24(4): 903-14

[8] Ginsburg PB. High and rising health care costs: demystifying U.S. health care spending (internet). Princeton (NJ): Robert Wood unmasked patient safety concerns such as domestic and community violence, reckless driving, etc. (17) added to the irresponsible spending in this country that we all love.

The best-practice guidelines based on scientific medical evidence can help cut unjustifiable costs by avoiding care not based on demonstrable, value-added, cost-effective principles. This will challenge the existing, traditional art of medicine and may sensibly limit the endless increase in health care costs. It will certainly stimulate our beliefs, broad-based input, and decision-making skills.

In conclusion, it is you and me who is going to emotionally and financially pay for this madness, not the insurance or the drug companies. Reasoning and rationalization for health care delivery has been a long part of humanity, however, it must be re-evaluated and modernized because the respect for human dignity, honesty, end of life decisions is what is going to save us from our self-destruction.

Johnson Foundation; 2008 Oct (cited 2009 Jun 17). Research synthesis report. P. 10. Available from

http//www.rwjf.org/files/research/101508.polic ysunthesis.costdrivers.rpt.pdf

[9] Aaron HJ, Schwartz WB. The painful prescription: rationing hospital care. Washington (DC): Brookings Institution: 1984.

[10] Somers A. The rationalization of health services: A universal priority. 1971, Inquiry 8: 48-60. Google scholar.

[11] Mushkin SJ. Health as an investment. Journal of political economy. 1962; 70(part II): 129157. Google scholar.

[12] Freidson E. Profession of Medicine. Dodd, Mead and Company, New York, 1971: (a) 205212, (b) 158-184; (c) 87-90. Google scholar.

[13] Vladeck BC. Everything new is old again. Health Aff (Millwood). 2004; 23: VAR-III.

[14] Angrisano C, Farrell D, Kocher B, Laboissiere M, Paker S. Accounting for the cost of health care in the United States (internet). San Francisco (CA): McKidnsey Global Institute. 2007 Jan (cited 2009 Jun 17). Available from http//www.mckinsey.com/mgi/rp/healthcare/ac counting_cost_healthcare.asp.

[15] ABC News/Kaiser Family Foundation/USA Today. Health care in America 2006 survey (internet). Menlo Park (CA): Kaiser Family Foundation: 2006 Oct (cited 2009 Jun 17) Available from http/www.kff.org/kaiserpolls/ upload/7572.pdf.

[16] White J. Cost control and health care reform: the case for all-payer regulation. Washington 
(DC): Campaign for America's Future; 2009. Available from http//www.ourfuture.org/healt hcare/white
[17] Morone JA. The bias of American politics: rationing health care in a weak state. $\mathrm{U} P \mathrm{~Pa}$ Rev 1992; 150: 1923-38.

Citation: Awad Magbri, Suhail Aftab, Anita Moses, Karen Miller. It is Perilous to be Old and Frail in the Land of More. ARC Journal of Public Health and Community Medicine. 2020; 5(1):5-7.DOI: dx.doi.org/ 10.20431/ 2456-0596.0501002.

Copyright: (C) 2020 Authors. This is an open-access article distributed under the terms of the Creative Commons Attribution License, which permits unrestricted use, distribution, and reproduction in any medium, provided the original author and source are credited. 